This is an author produced version of a paper published in Chemosphere. This paper has been peer-reviewed but does not include the final publisher proofcorrections or journal pagination.

Citation for the published paper:

Hagmar, Lars and Wallin, Ewa and Vessby, Bengt and Jonsson, Bo Ag and Bergman, Ke and Rylander, Lars

"Intra-individual variations and time trends 1991-2001 in human serum levels of PCB, DDE and hexachlorobenzene.”

Chemosphere. 2006 Feb 6; [Epub ahead of print]. http://dx.doi.org/10.1016/j.chemosphere.2005.12.054.

Access to the published version may require journal subscription.

Published with permission from: Elsevier. 


\section{Intra-individual variations and time trends 1991-2001 in human serum levels of PCB, DDE and hexachlorobenzene}

Lars Hagmar $^{\mathrm{a}^{*}}$, Ewa Wallin ${ }^{\mathrm{a}}$, Bengt Vessby ${ }^{\mathrm{b}}$, Bo AG Jönsson ${ }^{\mathrm{a}}$, Åke Bergman $^{\mathrm{c}}$, and Lars Rylander ${ }^{\mathrm{a}}$

${ }^{a}$ Division of Occupational and Environmental Medicine and Psychiatric Epidemiology, Department of Laboratory Medicine, Lund University Hospital, 22185 Lund, Sweden

${ }^{b}$ Unit for Clinical Nutrition Research, Department of Public Health and Caring Sciences, University of Uppsala, SE-751 85 Uppsala, Sweden

${ }^{c}$ Department of Environmental Chemistry, Stockholm University, SE-10691 Stockholm, Sweden

Fax: +4646173669, e-mail: lars.hagmar@med.lu.se 


\section{Abstract}

Background: An important question is whether human serum levels of persistent organic pollutants have continued to decrease during the last decades. The aim of this study was to assess intra-individual variations over time of serum levels of $2,2^{\prime}, 4,4^{\prime}, 5,5^{\prime}-$ hexachlorobiphenyl (CB-153), 1,1-dichloro-2,2-bis(4-chlorophenyl)-ethene (p,p'-DDE) and hexachlorobenzene (HCB), considering the impact of a number of possible determinants. Methods: Blood samples were drawn for the same 39 subjects in 1991 and 2001. Interviews were made at both occasions. Lipid adjusted serum concentrations of CB-153, p,p'-DDE and $\mathrm{HCB}$ were determined in both sets of blood samples using gas-chromatography-mass spectrometry. The fatty acid composition of the serum lipids was analyzed by means of gasliquid chromatography

Result: The CB-153 concentrations in serum had averagely decreased with 34\%in between 1991 and $2001(\mathrm{p}<0.001)$. Of individual determinants only increasing BMI was associated with decreasing CB-153 levels ( $\beta=-1.0,95 \% \mathrm{CI}-1.8,-0.2, \mathrm{p}=0.01$ ), explaining $13 \%$ of the variation. The average decrease of p,p'-DDE was $55 \%$, and could only weakly be associated with a relative increase of BMI $(\beta=-1.0,95 \% \mathrm{CI}-2.3,0.2, \mathrm{p}=0.09)$, explaining only $5 \%$ of the variation. The average decrease of $\mathrm{HCB}$ was $53 \%$, and was associated only with high fish consumption in 1991, explaining $12 \%$ of the variation.

Conclusions: The results support a continuing decrease in human body burdens of PCBs, DDE and HCB during the 1990's. The explanatory factors relative change of BMI and fish consumption explained only a minor part of the time-related variations in serum levels.

Keywords: Body Mass Index; Dietary contamination; Exposure determinants; Follow up study 


\section{Introduction}

An important question is whether human serum levels of persistent organic pollutants (POPs) has continued to decrease during the last decades. The main exposure source for POPs in western societies is dietary intake of animal fats (WHO, 2003). In Sweden, fatty fish from the Baltic Sea off the Swedish east coast is an important dietary source (Svensson et al., 1991; Asplund et al., 1994; Svensson et al., 1995). Analyses of the POP content in fish from the Baltic Seas have been performed in Sweden since the early 1970's, showing a considerable decrease over time, which, however, has slowed down or even levelled off during recent years (Bignert \& Asplund, 2003). A time-trend study of organochlorines from the 1970's and onwards of pooled breast milk samples from primipara women in the Stockholm region has also shown decreasing POP levels over time (Norén \& Meironyte, 2000). Based on chemical analyses of different food items and dietary surveys in the population the Swedish Food Agency has made a theoretical estimate that the dietary intake of POPs has decreased by twothirds during the 1990's (Lind et al., 2002).

There is need for more direct information about the intra-individual variation of body burden for POPs over time, considering the impact of possible explanatory factors such as changes in food contamination, changes in individual dietary habits, and other individual factors.

Three POPs that are detected in highest concentration in human serum are $2,2^{\prime}, 4,4^{\prime}, 5,5^{\prime}-$ hexachlorobiphenyl (CB-153), 1,1-dichloro-2,2-bis(4-chlorophenyl)-ethene (p,p'-DDE) and hexachlorobenzene (HCB). CB-153 belongs to the large group of PCBs, which have been banned in Sweden since the 1970's. There is, however, still a remaining problem with leakage of PCB from sealants and other construction materials used in the 1950's to 1970's. Moreover, the long range transport of PCBs related to air and water streams means that the environmental levels in Sweden is not dependent only on the effectiveness of national 
preventive measures. CB-153 serves as a good general biomarker for PCB exposure, because it correlates very well with total PCB concentration in plasma and serum (Grimvall et al., 1997; Glynn et al., 2000). CB-153 concentrations also correlate well with total POP derived dioxin-like exposure (Gladen et al., 1999).

The insecticide dichlorodiphenyl trichloroethane (DDT), was used in Sweden until it was banned in the 1970's, but it is still used in many parts of the world especially for malaria vector control. Due to the global long-range transport and to its high persistence, $p, p$ '-DDE, which is the main DDT metabolite, is ubiquitous in all food-chains.

HCB has previously been used as a fungicide, but it can also inadvertently be formed at uncontrolled burning of waste or in several industrial processes.

The main aim of this study was to assess intra-individual variations over time of serum levels of the three analytes CB-153, p,p'-DDE and HCB, considering a number of possible explanatory factors for the variations. We were able to do this as we had access to blood samples drawn for the same subjects in 1991 and 2001, respectively, which were used for POP analyses.

\section{Subjects and methods}

\subsection{Study population and sampling in 1991}

In 1991 blood samples were collected among 43 men with a median age of 42 years (range

23-69) (Sjödin et al., 2000). Nineteen of them never ate Baltic Sea fish (zero-consumers), 12 had 4-8 meals per month of fatty fish from the Baltic Sea (moderate consumers), and the remaining 12 had 12-20 such meals per month (high consumers). CB-153, p,p'-DDE and HCB in serum was analyzed at the Department of Environmental Chemistry at Stockholm University as described elsewhere (Sjödin et al., 2000). Serum lipids were analyzed with enzymatic methods. We have used these published results in the present work for intra- 
individual comparisons with corresponding analyses performed on serum samples drawn in 2001.

\subsection{Study population and sampling at the repeated examination in 2001}

Efforts were made in 2001 to contact all 43 men for a renewed examination. Unfortunately, three of the men had deceased and another one had emigrated. However, all the other 39 men accepted a new interview and blood sampling. Of these 39, 18 had in 1991 been classified as zero, 12 as moderate and the remaining nine as high fish consumers (Table 1).

Venous blood was drawn into Vacutainer tubes that were centrifuged for $10 \min (3500$ rpm). Serum was transferred to ethanol washed glass bottles. All samples were coded and stored frozen at $-80^{\circ} \mathrm{C}$ before they were analyzed.

\subsection{Determination of CB-153, $p$, p'-DDE, and HCB in serum from 2001}

The analyses of the POPs were performed at the Department of Occupational and Environmental Medicine, Lund University. The serum levels of CB-153, p,p'-DDE and HCB were determined as previously described but with some modifications (Richthoff et al., 2003; Rignell Hydbom et al., 2004). Briefly, the CB-153, p, p'-DDE and HCB were extracted from the serum by solid phase extraction (SPE) using on-column degradation of the lipids and analysis by GC-MS. ${ }^{13} \mathrm{C}_{12}$-labeled CB-153, ${ }^{13} \mathrm{C}_{12}$-labeled p,p'-DDE and ${ }^{13} \mathrm{C}_{6}$-labeled HCB were used as an internal standards. The modifications compared to the pervious methods were that the SPE columns used was Chromabond ${ }^{\circledR}$ HR-P (Macherey-Nagel, Düren, Germany), that $0.5 \mathrm{~mL}$ serum was used and the samples were eluted with dichloromethane $(1.0 \mathrm{~mL})$. The selected ion monitoring of HCB was performed at $\mathrm{m} / \mathrm{z} 284$ while $\mathrm{m} / \mathrm{z} 290$ was used for the internal standard. The relative standard deviations, calculated from samples analyzed in duplicate at different days, was $6 \%$ at $1.9 \mathrm{ng} / \mathrm{mL}(\mathrm{n}=39)$ for $\mathrm{CB}-153,11 \%$ at $3.0 \mathrm{ng} / \mathrm{mL}$ 
$(\mathrm{n}=39)$ for $\mathrm{p}, \mathrm{p}^{\prime}-\mathrm{DDE}$ and $4 \%$ at $0.13 \mathrm{ng} / \mathrm{mL}(\mathrm{n}=39)$ for HCB. The detection limits were 0.05 $\mathrm{ng} / \mathrm{mL}$ for CB-153, $0.1 \mathrm{ng} / \mathrm{mL}$ for $\mathrm{p}, \mathrm{p}^{\prime}-\mathrm{DDE}$ and $0.02 \mathrm{ng} / \mathrm{mL}$ for HCB. The analyses of CB153, p, p'-DDE and HCB are part of the Round Robin inter-comparison program (Professor Dr. med. Hans Drexler, Institute and Out-Patient Clinic for Occupational, Social and Environmental Medicine, University of Erlangen-Nuremberg) with analysis results within the tolerance limits.

\subsection{Determination of lipids by enzymatic methods}

Serum concentrations of triglycerides, cholesterol and phospholipids were determined by enzymatic methods using reagents from Boehringer-Mannheim (triglycerides and cholesterol; Mannheim, Germany) and Waco Chemicals (phospholipids; Neuss, Germany). The total lipid concentration in plasma was calculated by summation of the amounts of triglycerides, cholesterol and phospholipids. In these calculations, the average molecular weights of triglycerides and phospholipids were assumed to be 807 and 714 . For cholesterol we used an average molecular weight of 571, assuming that the proportion of free and esterified cholesterol in plasma was 1:2.

\subsection{Fatty acid composition of serum lipid esters}

Fatty acids were analyzed in samples drawn in 1991 and 2001. The serum samples had been stored at $-80^{\circ} \mathrm{C}$ before analysis, and all samples were analysed at the same time at the Clinical research laboratory at the Department of Public Health and Caring Sciences at Uppsala University. The fatty acid composition of the serum lipids was analyzed by means of gasliquid chromatography (GLC), as described in detail elsewhere (Boberg et al., 1985). Briefly, the serum lipids were extracted in chloroform, separated by thin-layer chromatography, transmethylated and separated by GLC on a capillary column. The analyses were carried out 
on a GC 5890, equipped with a 7671A auto-injector, a 3392A integrator (all from HewlettPackard, Avondale, PA) and a 25-m Nordion fused silica column NS-351 (HNU Systems Inc, Finland), using helium as carrier gas. The temperature was programmed to $100-210{ }^{\circ} \mathrm{C}$. The fatty acids were identified by comparing each peak's retention time with those of methyl ester standards (GLC- 68A, Nu Check Prep, Elysian, MN, USA). The relative amount of each fatty acid ( $\%$ of total fatty acids) was quantified by integrating the area under the peak and dividing the results by the total area for all fatty acids. The coefficients of variations for the analyses were $<10 \%$ for all fatty acids in both phospholipids and cholesteryl esters, except for 15:0 in cholesteryl esters with $\mathrm{CV}=13.4 \%$.

\subsection{Statistics}

Pair-wise comparisons of the POP levels in 1991 and 2001 were made with Wilcoxon's ranksum test. Comparisons between fish-eaters and non-fish eaters with respect to n3-PUFA were made with Mann-Whitney’s U-test. Bivariate correlations were assessed by Spearman’s correlation coefficients. Linear regression models were used to estimate the effect of age, relative change in body mass index, and consumption of fatty fish from the Baltic Sea on the relative change in individual POP levels between 1991 and 2001. Consumption of fatty fish from the Baltic Sea as exposure was considered in three ways: 1) classification of subjects made in 1991 (zero, moderate, and high consumers), 2) relative change of consumption between 1991 and 2001, or 3) sum of n3-PUFA levels in 1991 and 2001, respectively. If the variables in the univariate analyses showed any association $(\mathrm{p}<0.10)$ with the relative change in individual POP levels between 1991 and 2001, they were included in the multivariate models. Model assumptions were checked by residual analyses. 


\section{Results}

There was for the 1991 data a strong association between the sum of n3-PUFA concentrations and intake of fatty fish from the Baltic Sea (Figure 1). The non-fish eaters had significantly lower levels of $n 3$-PUFA as compared with the fish eaters $(p<0.001)$ However, there were no significant correlation between the levels of n3-PUFA and fish intake among the fish eaters $\left(r_{s}=0.20, p=0.38\right)$. The pattern was very similar regarding year 2001 data. The average intake of fatty fish from the Baltic Sea had significantly decreased over the 10 year observation period ( $\mathrm{p}=0.001)$, whereas the levels of the sum of n3-PUFAs had increased over the years $(p<0.001)$. This was in contrast to the n6-PUFA levels which were virtually unchanged between 1991 and 2001 (Table 1).

The intra-individual correlation of CB-153 levels between 1991 and 2001 was very high $\left(r_{s}=0.90 ; p<0.001 ;\right.$ Figure 2a). The CB-153 levels in serum had decreased in 37 out of the 39 subjects since $1991(\mathrm{p}<0.001)$ and with an average decrease of $34 \%$ over the observation period (Table 2). The relative change of CB-153 in serum was not related to age $(p=0.47)$, fish consumption group in 1991 ( $p>0.5$ ), the relative change in individual consumption of fatty fish from the Baltic Sea between 1991 and $2001(\mathrm{p}=0.52)$ or the sum of $\mathrm{n} 3$-PUFAs in 1991 and 2001 ( $\mathrm{p}$-values $>0.3$ ). On the other hand, there was a significant negative association between relative change in BMI over time and relative change in CB-153 over time $(\beta=-1.0,95 \% \mathrm{CI}-1.8,-0.2, \mathrm{p}=0.01$, Figure 3$)$. However, BMI explained only $13 \%$ of the variation (adjusted $\mathrm{R}^{2}$ ) in the relative change in CB-153 levels over time. This association was almost the same also when we excluded the individual with an extreme relative change in CB153 over time ( $72 \%$ increase) from the analysis (data not shown).

The intra-individual correlation of p,p'-DDE levels between 1991 and 2001 was very high $\left(r_{s}=0.92 ; p<0.001\right.$, Figure $\left.2 b\right)$ and for all but one of the 39 participants the levels of $p, p$ DDE in serum had decreased since $1991(\mathrm{p}<0.001)$. The average decrease in $\mathrm{p}, \mathrm{p}$-DDE over 
the observation period was $55 \%$ (Table 2). The relative change in p,p'-DDE was not related to age $(p=0.51)$, fish consumption group in $1991(p>0.5)$, the relative change in consumption of fatty fish from the Baltic Sea between 1991 and 2001 ( $p>0.5)$, or the sum of n3-PUFAs in 1991 and 2001 ( $p$-values $>0.5$ ), but a weak association was found with relative change of BMI over the time $(\beta=-1.0,95 \% \mathrm{CI}-2.3,0.2, \mathrm{p}=0.09)$. Relative change of BMI over time explained only $5 \%$ of the variation (adjusted $\mathrm{R}^{2}$ ) in the relative change in p,p'-DDE levels over time. By excluding an extreme individual (with a relative increase of p,p'-DDE of 154 $\%)$ from the analyses the association became statistically significant $(\beta=-0.6,95 \% \mathrm{CI}-1.1$, $0.1, \mathrm{p}=0.01$, adjusted $\mathrm{R}^{2}=14 \%$ ).

The intra-individual correlation of HCB levels between 1991 and 2001 was very high $\left(r_{s}=0.91 ; p<0.001\right.$; Figure $\left.2 c\right)$, but for all 39 participants the levels of HCB in serum had decreased since $1991(\mathrm{p}<0.001)$. The average decrease over the observation period in HCB was $53 \%$ (Table 2 ). The relative change in $\mathrm{HCB}$ was not significantly related to age $(\mathrm{p}=0.07)$, relative change of BMI over the time $(\mathrm{p}>0.5)$, the relative change in consumption of fatty fish from the Baltic Sea between 1991 and 2001 ( $p=0.53)$, or the sum of n3-PUFAs in 1991 and 2001 (p-values >0.10). On the other hand, fish consumption group in 1991 was of importance. Subjects with moderate/high consumption had relatively decreased their serum levels more than the zero consumers (mean difference $9.7 \mathrm{ng} / \mathrm{g}, 95 \%$ CI $1.8-18, \mathrm{p}=0.02$ ). There was, however, no significant difference between the moderate and high consumers group $(\mathrm{p}=0.40)$. By including age and fish consumption group in the models simultaneously, the effect of fish consumption still persisted, whereas the association with age became even weaker $(\mathrm{p}=0.17)$. However, fish consumption group explained only $12 \%$ of the variation (adjusted $\mathrm{R}^{2}$ ) in the relative change in $\mathrm{HCB}$ levels over time. 
The relative change over time of CB-153 and p,p'-DDE correlated well $\left(\mathrm{r}_{\mathrm{s}}=0.71\right.$, $\mathrm{p}<0.001)$, whereas the correlation was non-significant between CB-153 and $\mathrm{HCB}\left(\mathrm{r}_{\mathrm{s}}=0.10\right.$, $\mathrm{p}=0.52)$ and between $\mathrm{p}, \mathrm{p}^{\prime}-\mathrm{DDE}$ and $\mathrm{HCB}\left(\mathrm{r}_{\mathrm{s}}=0.24, \mathrm{p}=0.14\right)$.

\section{Discussion}

The most pertinent finding of the present study was the significant intra-individual decreases from 1991 to 2001 of serum levels for CB-153 (averagely 34\%), p,p'-DDE (averagely 55\%) and HCB (averagely 53\%). Only few previous studies have used repeated sampling in the same subjects allowing assessment of time trends of body burdens of POP for specific individuals (Hovinga et al 1992; Wolff et al 2000; Hoyer et al 2000, Sweeney et al 2001), and not only population time trends as in most earlier studies (Norén, 1993; Schade \& Heinzow, 1998; Waliszewski et al., 1998; Harris et al., 1999; Norén \& Meironyte, 2000; He et al., 2001; Dallaire et al., 2002; Dallaire et al., 2003). Between 1982 and 1989 serum concentrations of $\mathrm{p}, \mathrm{p}$ 'DDE decreased with averagely $40 \%$ among Great Lakes fish eaters, while the decrease was only $29 \%$ among non-fish eaters (Hovinga et al 1992). Virtually no change in PCB levels was observed over the seven year period. Repeated sampling from 1986 and onwards in healthy females from New York indicated median "half-lives" of 8.6 years for DDE and 11.2 years for PCB (Wollf et al 2000). In a Danish study on females CB153 decreased with averagely $9 \%$ over a five year period (1977 to 1982), whereas the p,p'DDE levels did not change over time (Hoyer et al 2000). The discrepant findings are not surprising because the studies vary with respect to gender, geographical setting and time period of sampling. The two latter aspects reflect the different environmental exposure situations for POPs

The most likely explanation for the observed general decrease in serum levels of POPs, is the decreased POP contamination in fatty fish and other food items (Lind et al., 2002; Bignert 
\& Asplund, 2003). Based on chemical analyses of different food items and dietary surveys in the population, the Swedish Food Agency has made a theoretical estimate that the dietary intake of POP has decreased by two-thirds during the 1990's (Lind et al., 2002). The presently observed 34-55\% decrease in body burden over the same time periods, fits therefore rather well with these dietary intake estimates.

We tested a number of potential individual determinants for assessing the interindividual variations in serum levels over time (age, fish consumption in 1991, relative change in fish consumption 1991-2001, n3-PUFA in 1991, n-3 PUFA in 2001, and relative change in BMI 1991-2001). However, besides relative change in BMI over time for CB-153 and p,p'-DDE, and fish consumption in 1991 for $\mathrm{HCB}$, these individual determinants were not of any importance. The more BMI had increased over time the larger the relative decrease in CB-153 and p,p'-DDE over time. This is a reasonable finding as the distribution volume (adipose tissue) for the lipid soluble POPs increases with increasing BMI. This finding is in concordance with that of Hoyer et al for CB-153 (2000). Wollf et al found a similar inverse correlation with BMI change over time, but only for DDE and not for PCB (2000).

The decrease in HCB over time was highest among those with high or moderate fish consumption in 1991. Altogether, the explanatory values of the individual determinants assessed were low (5-13\%), which means that for most of the inter-individual variation of POP levels over time there must be other explanations.

The main reason for analysing $n 3$ and $n 6$ PUFA in serum was to obtain a more objective measure of intake of fatty fish than the self-reported frequency. The correlations showed reasonably good fits between n3-PUFA in serum and self-reported fish intake, which is in accordance with previous findings (Svensson et al., 1991). A more puzzling finding was that the n3-PUFA levels generally were higher in samples from 2001 as compared with 
samples from 1991, whereas the consumption of fatty fish from the Baltic Sea had decreased during the observation period. A possible explanation for this might be changed composition of fatty acids in Swedish margarines during the 1990's, due to change from soybean oil to rapeseed oil as the major source of polyunsaturated fatty acids, which resulted in an increase of linolenic acid and a decrease of linolic acid in the products (Wulf Becker, personal communication).

It has to be emphasized that the analyses for CB-153, p, $\mathrm{p}^{\prime}$-DDE, and HCB in samples from 1991 and 2001, respectively, are neither performed at the same time nor at the same laboratory. However, the high intra-individual correlations between samples from 1991 and $2001(\mathrm{r}=0.92-0.98)$, give some circumstantial evidence for that the comparisons are justified. Moreover, both laboratories have participated in Round Robin inter-comparison programs showing results within the reference intervals.

In conclusion, the results of the present study support a continuing decrease in human body burdens of PCBs, DDE and HCB during the 1990's. The explanatory factors relative change of BMI and fish consumption explained only a minor part of the time-related variations in serum levels.

\section{Acknowledgements}

The work has been funded by the Swedish Environmental Protection Board. Authors thank Ms Hélène Åkesson for performing chemical analyses in a skilful way.

\section{References}

Asplund L, Svensson B-C, Nilsson A, Eriksson U. Jansson B, Jensen S, Wideqvist U, Skerfving S., 1994. Polychlorinated biphenyls, 1,1,1-trichloro-2-2-bis(p- 
chlorophenyl)ethane (p,p'-DDT) and 1,1-dichloro-2,2-bis(p-chlorophenyl)-ethylene (p,p'DDE) in human plasma related to fish consumption. Arch. Environ. Health 49, 477-486.

Bignert A, Asplund L., 2003. Comments concerning the Swedish contaminant monitoring programme in marin biota. Report from the Contaminant research group at the Swedish Museum of the Natural History, 2003.

Boberg M, Croon LB, Gustafsson IB, Vessby B., 1985. Platelet FA-composition in relation to Fatty Acid composition in plasma and to serum lipoprotein lipids in healthy subjects with specific reference to the linoleic acid pathway. Clinical Science 68, 581-587.

Dallaire F, Dewailly É, Laliberte C, Muckle G, Ayotte P., 2002. Temporal trends of organochlorine concentrations in umbilical cord blood of newborns from the lower north shore of the St. Lawrence river (Québec, Canada). Environ. Health Perspect. 110, 835838.

Dallaire F, Dewailly É, Muckle G, Ayotte P., 2003. Time trends of persistent organic pollutants and heavy metals in umbilical cord blood of Inuit infants born in Nunavik (Québec, Canada) between 1994 and 2001. Environ. Health Perspect. 111, 1660-1664.

Gladen BC, Longnecker MP, Schechter AJ., 1999. Correlations among polychlorinated biphenyls, dioxins, and furans in humans. Am. J Ind. Med. 35:15-20.

Grimvall W, Rylander L, Nilsson-Ehle P, Nilsson U, Strömberg U, Hagmar L, Östman C., 1997. Monitoring of polychlorinated biphenyls in human blood plasma with respect to age, lactation and fish consumption; methodology developments. Arch. Environ. Contam. Toxicol. 32, 329-336.

Harris CA, O’Hagan S, Merson GH., 1999. Organochlorine pesticide residues in human milk in the United Kingdom 1997-8. Hum. Exp. Toxicol. 18, 602-606. 
He JP, Stein AD, Humphrey HE, Paneth N, Courval JM., 2001. Time trends in sport-caught Great Lakes fish consumption and serum polychlorinated biphenyl levels among Michigan Anglers, 1973-1993. Environ. Sci. Technol. 35, 435-440.

Hovinga, ME, M. Sowers M, Humphrey HE., 1992. Historical changes in serum PCB and DDT levels in an environmentally-exposed cohort. Arch. Environ. Contam. Toxicol. 4, 362-366.

Hoyer AP, Jorgensen T, Grandjean P, Harvig HB., 2000. Repeated measurements of organochlorine exposure and breast cancer risk (Denmark). Cancer Causes Control 11, 177-184.

Lind Y, Darnerud PO, Aune M, Becker W., 2002. Exponering för organiska miljökontaminanter via livsmedel. Rapport 26-2002, Livsmedelsverket, Uppsala. (In Swedish)

Noren K, Meironyte D., 2000. Certain organochlorine and organobromine contaminants in Swedish human milk in perspective of past 20-30 years. Chemosphere 40, 1111-1123. Noren K., 1993. Contemporary and retrospective investigations of human milk in the trend studies of organochlorine contaminants in Sweden. Sci. Total Environ. 139-140, 347355.

Schade G, Heinzow B., 1998. Organochlorine pesticides and polychlorinated biphenyls in human milk of mothers living in northern Germany: current extent of contamination, time trend from 1986 to 1997 and factors that influence the levels of contamination. Sci. Total Environ. 215, 31-39.

Sjödin A, Hagmar L, Klasson-Wehler E, Björk J, Bergman Å., 2000. Influence of the consumption of fatty Baltic Sea fish on plasma levels of halogenated environmental contaminants in Latvian and Swedish men. Environ. Health Perspect. 108, 1035-1040. 
Svensson B-G, Nilsson A, Hansson M, Rappe C, Åkesson B, Skerfving S., 1991. Exposure to dioxins and dibenzofurans through the consumption of fish. N Engl J Med 324, 8-12.

Sweeney AM, Symanski E, Burau KD, Kim YJ, Humphrey HEB, Smith MA., 2001. Changes in serum PBB and PCB levels over time among women of varying ages at exposure. Environ. Res. 86, 128-139.

Waliszewski SM, Aguirre AA, Infanzon RM, Rivera J, Infanzon R.,1998. Time trend of organochlorine pesticide residues in human adipose tissue in Veracruz, Mexico: 19881997 survey. Sci. Total Environ. 221, 201-204.

Wolff MS, Zeleniuch-Jacquotte A, Dubin N, Toniolo P., 2000. Risk of breast cancer and organochlorine exposure. Cancer Epidemiol. Biomarkers Prev. 9, 271-277.

World Health Organization. 2003, Polychlorinated Biphenyls, Human Health Effects. Concise International Chemical Assessment Document, Vol 55. Geneva:WHO. 


\section{FIGURE CAPTIONS}

Fig. 1. Correlation between intake of fatty fish from the Baltic Sea and the sum of n3-PUFA levels $(18: 3,20: 5,22: 5,22: 6)$ in serum in 1991 from 39 Swedish men $\left(r_{s}=0.70 ; p<0.001\right)$.

Fig. 2a. Correlation between 1991 and 2001 serum levels of $2,2^{\prime}, 4,4^{\prime}, 5,5^{\prime}-$ hexachlorobiphenyl (CB153) in 39 Swedish men $\left(\mathrm{r}_{\mathrm{s}}=0.90 ; \mathrm{p}<0.001\right)$.

Fig. 2b. Correlation between 1991 and 2001 serum levels of 1,1-dichloro-2,2-bis(4chlorophenyl)-ethene ( $\left.\mathrm{p}, \mathrm{p}^{\prime}-\mathrm{DDE}\right)$ in 39 Swedish men $\left(\mathrm{r}_{\mathrm{s}}=0.92 ; \mathrm{p}<0.001\right)$.

Fig. 2c. Correlation between 1991 and 2001 serum levels of hexachlorobenzene (HCB) in 39 Swedish men $\left(\mathrm{r}_{\mathrm{s}}=0.91 ; \mathrm{p}<0.001\right)$.

Fig. 3. Correlation between relative change (\%) between 1991 and 2001 of body mass index (BMI) and 2,2',4,4',5,5'-hexachlorobiphenyl (CB153) in serum of 39 Swedish men $\left(r_{s}=-0.43 ; p=0.01\right)$. 
Figure 1.

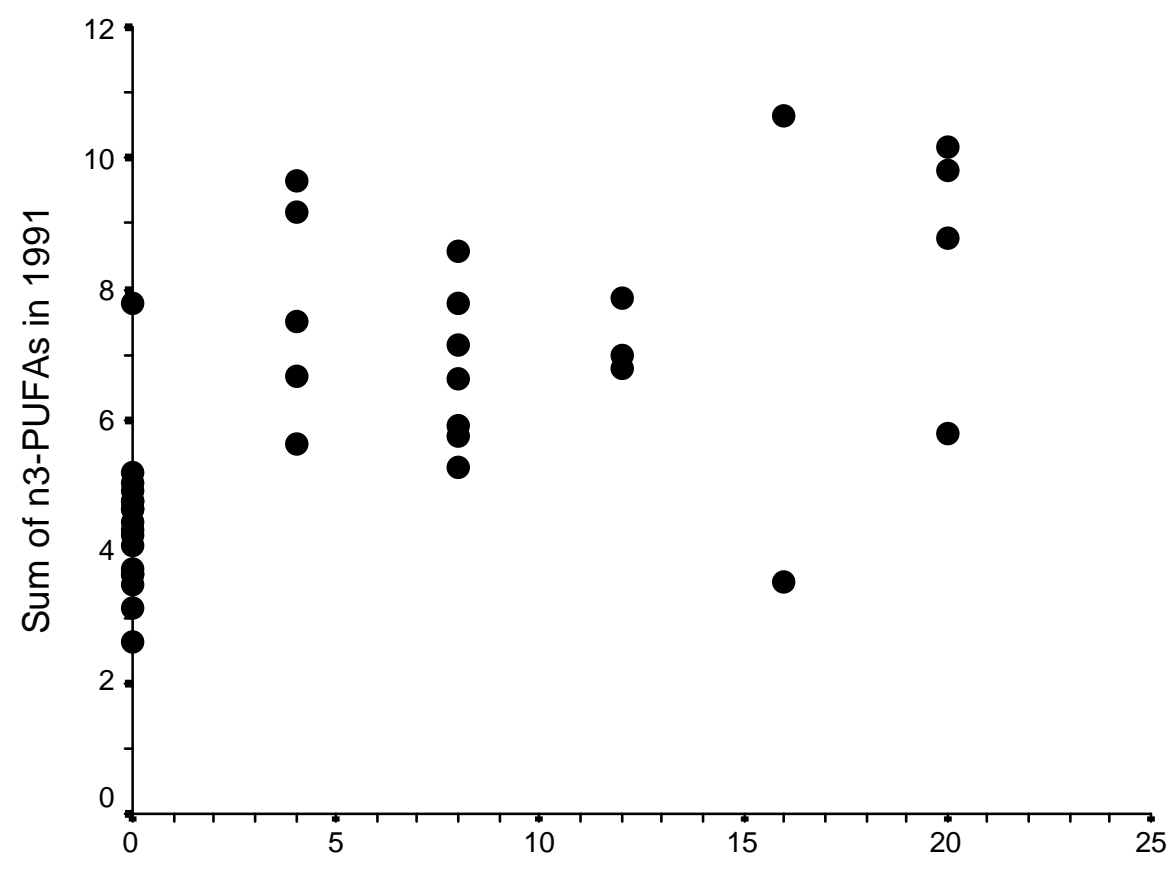

Fatty fish from the Baltic Sea in 1991 (meals/month) 
Figure 2a.

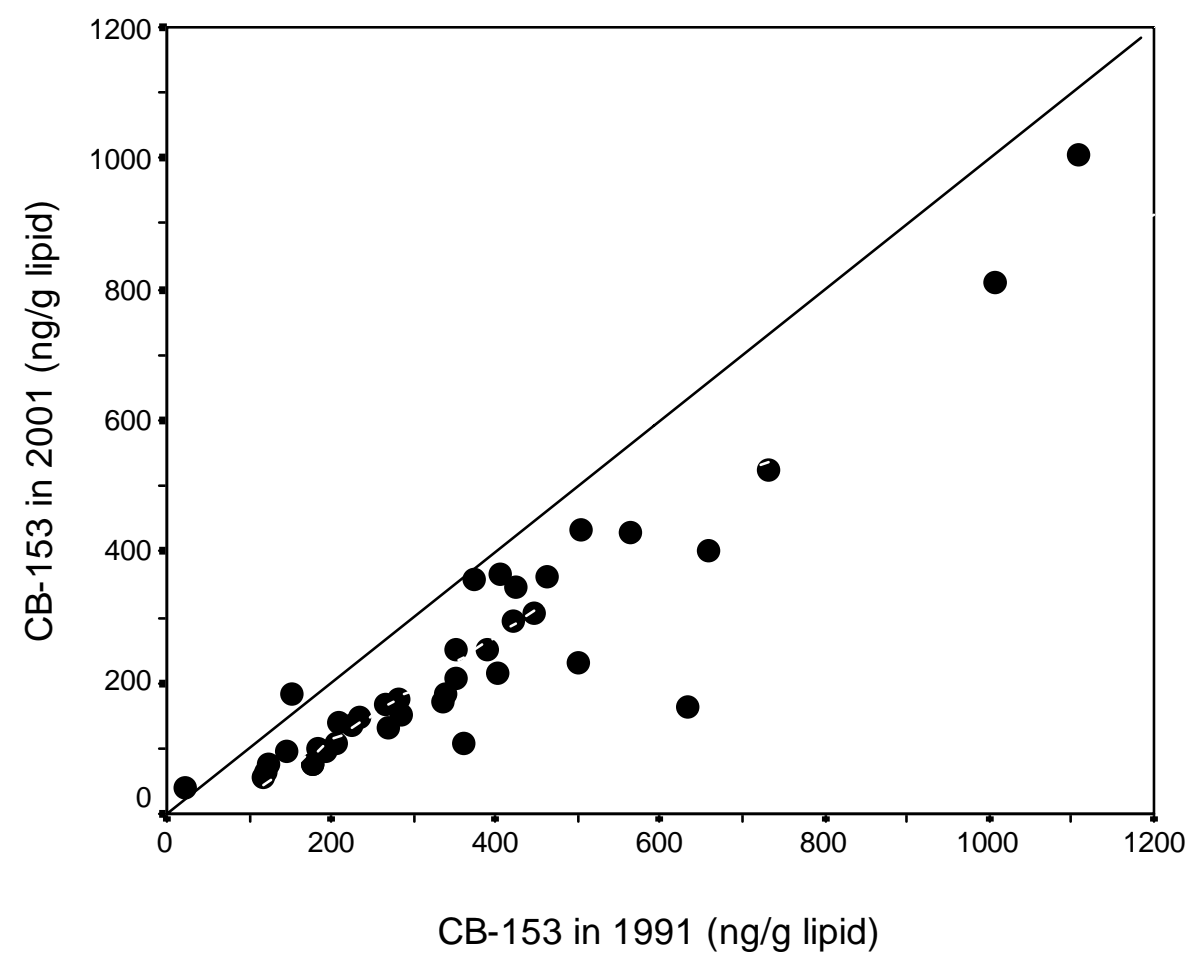


Figure $2 b$.

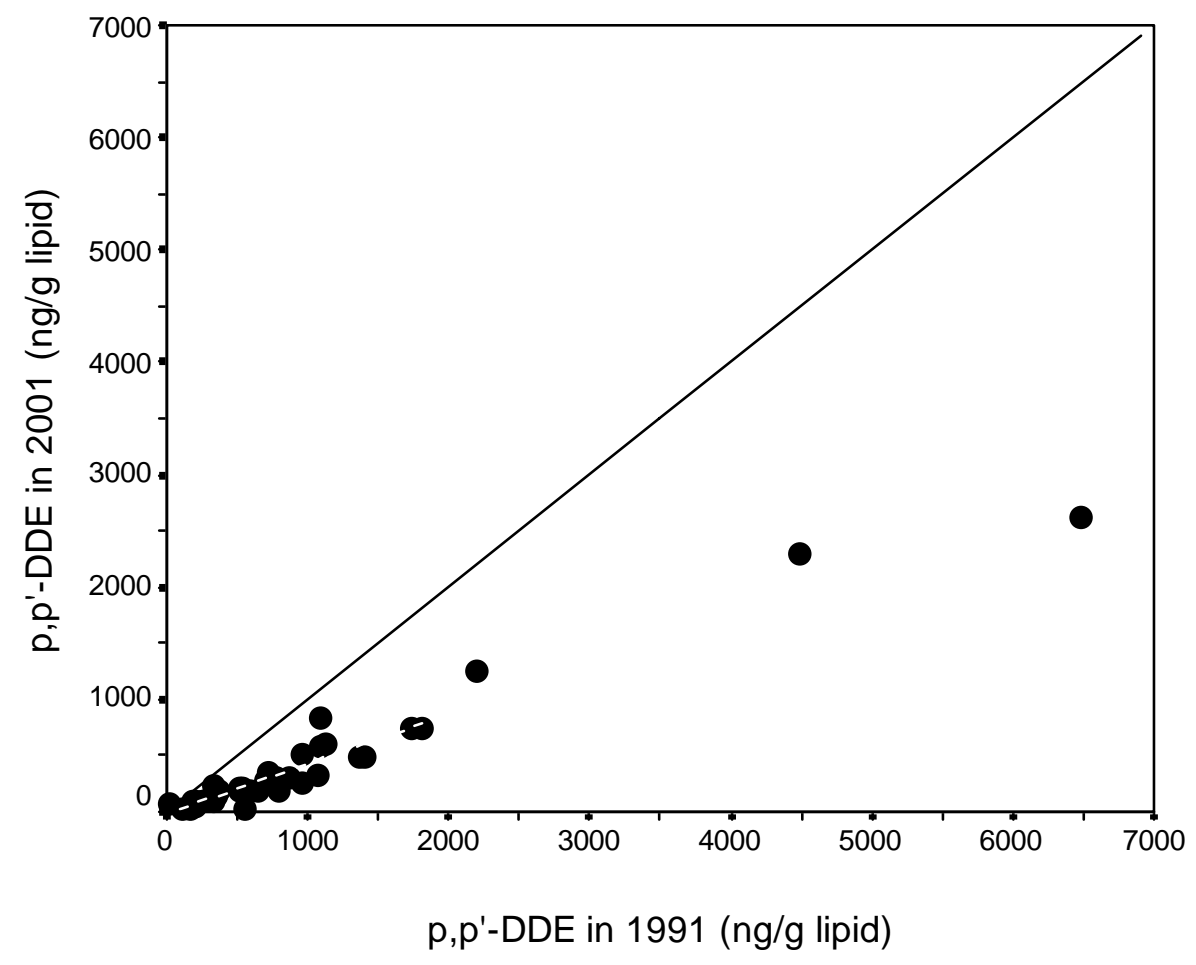


Figure 2c.

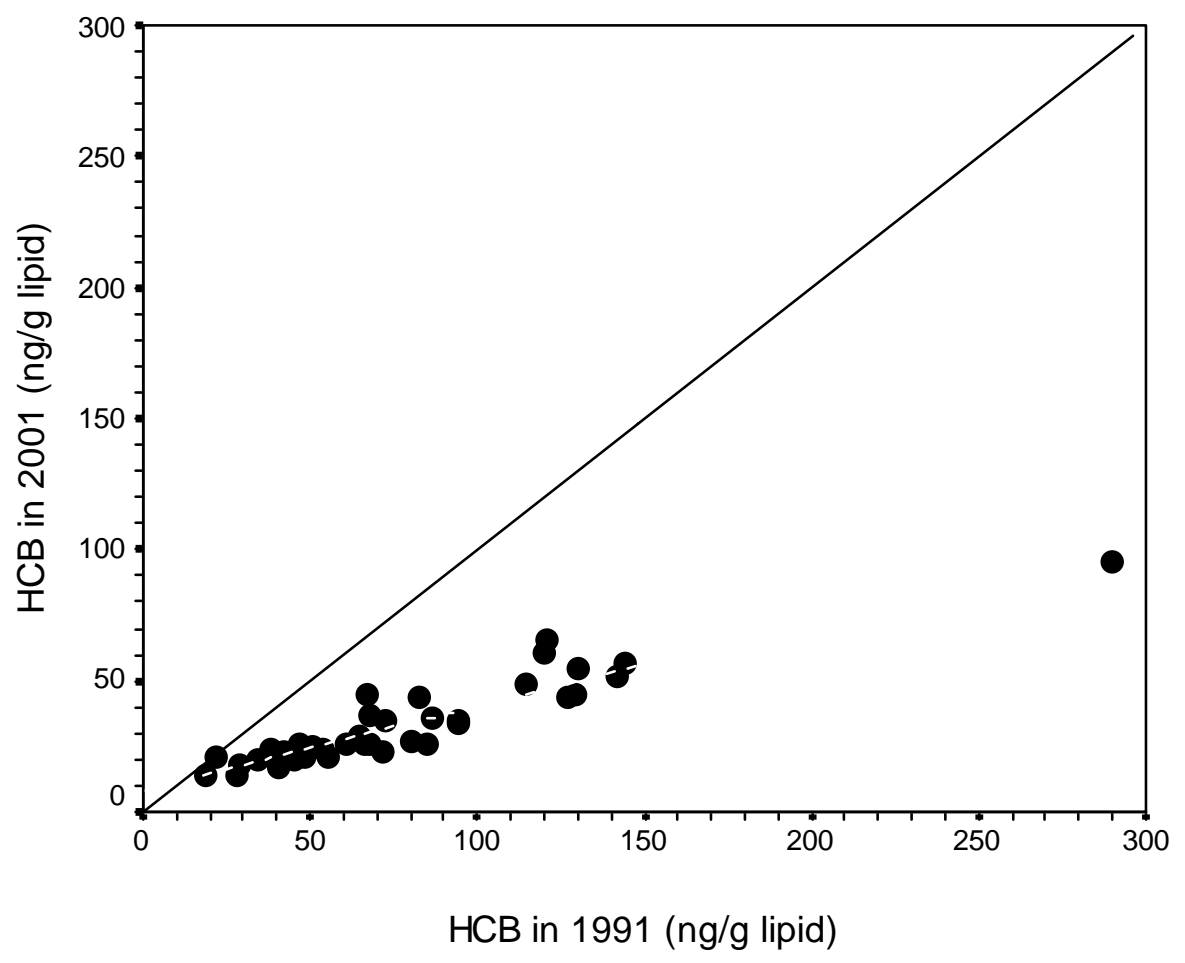


Figure 3.

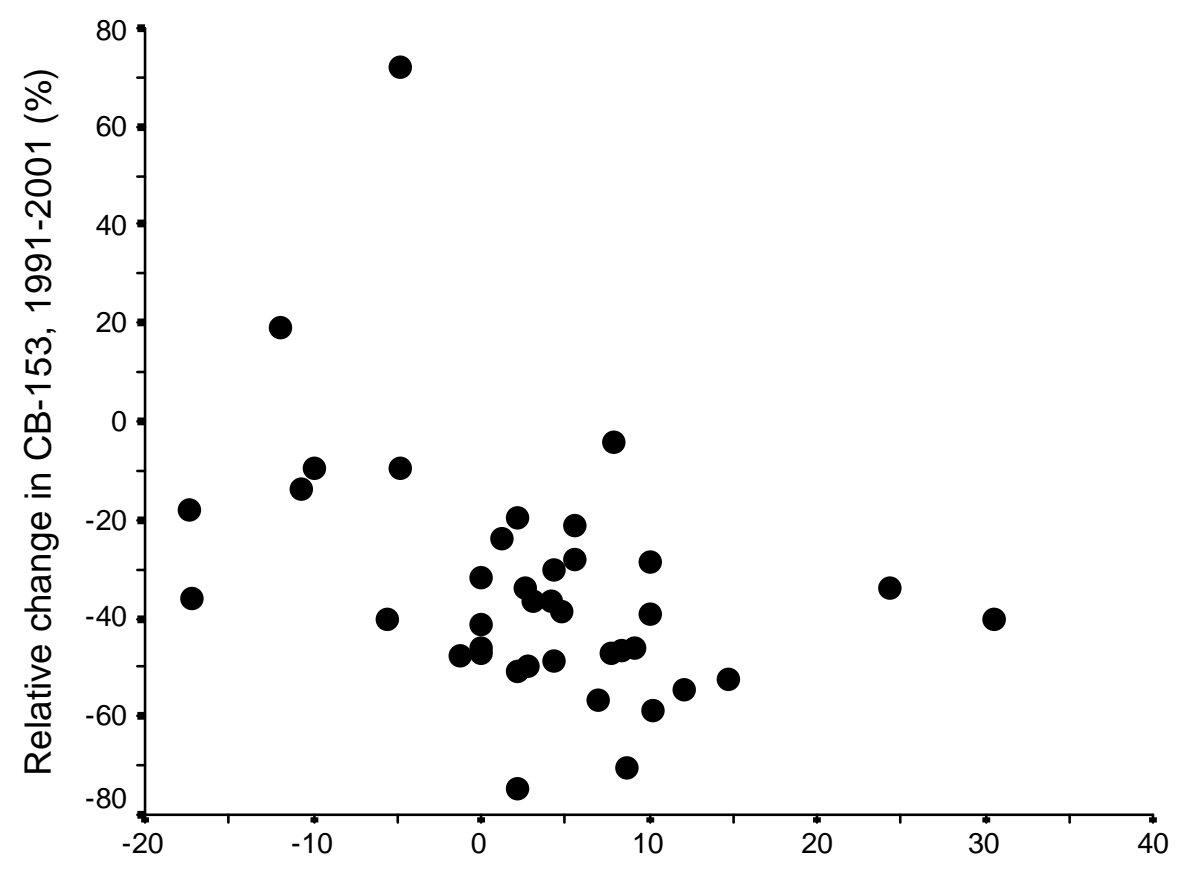

Relative change in BMI, 1991-2001 (\%) 
Table 1. Age, BMI, intake of fatty fish from the Baltic Sea, sum of n3-PUFA and sum of n6-PUFA, in 1991 and 2001, and the relative change between 1991 and 2001, by fish consumption group in 1991.

\begin{tabular}{|c|c|c|c|c|c|c|c|c|c|c|c|c|c|c|}
\hline & & \multirow{3}{*}{\begin{tabular}{|c|}
$\begin{array}{c}\text { Age } \\
(\mathrm{yr})\end{array}$ \\
1991 \\
\end{tabular}} & \multicolumn{3}{|c|}{ BMI } & \multicolumn{3}{|c|}{$\begin{array}{c}\text { Intake of fatty fish from } \\
\text { the Baltic Sea }\end{array}$} & \multicolumn{3}{|c|}{ Sum of n3-PUFA ${ }^{a}$} & \multicolumn{3}{|c|}{ Sum of n6-PUFA ${ }^{b}$} \\
\hline \multirow{2}{*}{\multicolumn{2}{|c|}{$\begin{array}{l}\text { Consumption of fatty } \\
\text { fish from the Baltic Sea } \\
\text { in } 1991\end{array}$}} & & \multicolumn{2}{|c|}{$\begin{array}{l}\text { Absolute } \\
\text { levels } \\
\left(\mathrm{kg} / \mathrm{m}^{2}\right)\end{array}$} & \multirow{2}{*}{$\begin{array}{c}\begin{array}{c}\text { Relative } \\
\text { change } \\
(\%)\end{array} \\
1991 \rightarrow 2001\end{array}$} & \multicolumn{2}{|c|}{$\begin{array}{l}\text { Absolute } \\
\text { levels } \\
\text { (meals/ } \\
\text { month) }\end{array}$} & \multirow[t]{2}{*}{$\begin{array}{c}\begin{array}{c}\text { Relative } \\
\text { change } \\
(\%)\end{array} \\
1991 \rightarrow 2001\end{array}$} & \multicolumn{2}{|c|}{$\begin{array}{l}\text { Percent of } \\
\text { total fatty } \\
\text { acids }\end{array}$} & \multirow[t]{2}{*}{$\begin{array}{c}\begin{array}{c}\text { Relative } \\
\text { change } \\
\text { over time } \\
(\%)\end{array} \\
1991 \rightarrow 2001\end{array}$} & \multicolumn{2}{|c|}{$\begin{array}{l}\text { Percent of } \\
\text { total fatty } \\
\text { acids }\end{array}$} & \multirow[t]{2}{*}{$\begin{array}{c}\text { Relative } \\
\text { change } \\
\text { over time } \\
(\%)\end{array}$} \\
\hline & & & 1991 & 2001 & & 1991 & 2001 & & 1991 & 2001 & & 1991 & 2001 & \\
\hline Zero & Mean & 40 & 25.0 & 26.4 & 5.9 & 0 & 0 & 0 & 4.4 & 5.8 & 38 & 32 & 33 & 2.8 \\
\hline \multirow[t]{3}{*}{$(\mathrm{N}=18)$} & Median & 38 & 24.9 & 25.7 & 3.6 & 0 & 0 & 0 & 4.4 & 5.6 & 36 & 33 & 33 & 2.6 \\
\hline & Min & 23 & 21.0 & 21.5 & -5.6 & 0 & 0 & 0 & 2.6 & 4.3 & -20 & 31 & 30 & -13 \\
\hline & Max & 62 & 30.2 & 31.8 & 31 & 0 & 2 & $-{ }^{c}$ & 7.8 & 7.7 & 100 & 34 & 36 & 18 \\
\hline \multirow{4}{*}{$\begin{array}{l}\text { Moderate } \\
(\mathrm{N}=12)\end{array}$} & Mean & 46 & 26.0 & 27.0 & 4.6 & 6 & 4 & -24 & 7.2 & 9.6 & 36 & 30 & 30 & 0.5 \\
\hline & Median & 42 & 25.4 & 26.6 & 6.7 & 8 & 3 & -50 & 6.9 & 9.4 & 35 & 32 & 31 & -1.9 \\
\hline & Min & 34 & 21.1 & 23.6 & -10 & 4 & 0 & -100 & 5.3 & 6.9 & -1.7 & 24 & 27 & -11 \\
\hline & Max & 69 & 34.2 & 30.8 & 12 & 8 & 9 & 125 & 9.6 & 13 & 76 & 35 & 33 & 16 \\
\hline \multirow{4}{*}{$\begin{array}{l}\text { High } \\
(\mathrm{N}=9)\end{array}$} & Mean & 43 & 30.4 & 28.8 & -4.3 & 16 & 5 & -70 & 7.8 & 8.4 & 17 & 29 & 32 & 8.8 \\
\hline & Median & 48 & 30.3 & 29.4 & 0.0 & 16 & 4 & -75 & 7.9 & 8.6 & 1.3 & 29 & 32 & 7.2 \\
\hline & Min & 23 & 21.6 & 21.6 & -17 & 12 & 1 & -94 & 3.5 & 6.5 & -13 & 23 & 28 & -4.0 \\
\hline & Max & 49 & 36.2 & 32.3 & 8.8 & 20 & 9 & -33 & 11 & 10 & 110 & 32 & 34 & 36 \\
\hline \multirow{4}{*}{$\begin{array}{l}\text { All } \\
(\mathrm{N}=39)\end{array}$} & Mean & 42 & 26.6 & 27.2 & 3.1 & 6 & 2 & -25 & 6.0 & 7.6 & 32 & 31 & 32 & 3.5 \\
\hline & Median & 42 & 25.6 & 27.4 & 3.1 & 4 & 2 & 0 & 5.7 & 7.3 & 32 & 32 & 32 & 2.8 \\
\hline & Min & 23 & 21.0 & 21.5 & -17 & 0 & 0 & -100 & 2.6 & 4.3 & -20 & 23 & 27 & -13 \\
\hline & Max & 69 & 36.2 & 32.3 & 31 & 20 & 9 & 125 & 11 & 13 & 110 & 35 & 36 & 36 \\
\hline
\end{tabular}

${ }^{a}$ Sum of n3-PUFA $=18: 3,20: 5,22: 5,22: 6$

Sum of n6-PUFA $=18 \cdot 2,20 \cdot 3,20: 4$

${ }^{\mathrm{c}}$ Two men had increased their consumption. They were not included in the analyses. 
Table 2. Absolute serum levels for 2,2',4,4',5,5'-hexachlorobiphenyl (CB-153), 1,1-dichloro-2,2-bis(4-chlorophenyl)-ethene (p,p'-DDE) and hexachlorobenzene (HCB) in 1991 and 2001, and absolute and relative changes in these levels between 1991 and 2001, in 39 Swedish men, considering their intake of fatty fish from the Baltic Sea in 1991.

\begin{tabular}{|c|c|c|c|c|c|c|c|c|c|c|c|c|c|}
\hline & & \multicolumn{4}{|c|}{ CB-153 } & \multicolumn{4}{|c|}{ p.p'-DDE } & \multicolumn{4}{|c|}{$\mathrm{HCB}$} \\
\hline \multirow{2}{*}{\multicolumn{2}{|c|}{$\begin{array}{l}\text { Consumption of fatty } \\
\text { fish from the Baltic Sea } \\
\text { in } 1991\end{array}$}} & \multicolumn{2}{|c|}{$\begin{array}{c}\text { Absolute } \\
\text { levels } \\
\text { (ng/g lipid) }\end{array}$} & \multirow{2}{*}{\begin{tabular}{|c|}
$\begin{array}{c}\text { Absolute } \\
\text { change } \\
\text { (ng/g lipid) }\end{array}$ \\
$1991 \rightarrow 2001$
\end{tabular}} & \multirow{2}{*}{$\begin{array}{c}\begin{array}{c}\text { Relative } \\
\text { change } \\
(\%)\end{array} \\
1991 \rightarrow 2001 \\
\end{array}$} & \multicolumn{2}{|c|}{$\begin{array}{c}\text { Absolute } \\
\text { levels } \\
\text { (ng/g lipid) }\end{array}$} & \multirow{2}{*}{\begin{tabular}{|c|}
$\begin{array}{c}\text { Absolute } \\
\text { change } \\
\text { (ng/g lipid) }\end{array}$ \\
$1991 \rightarrow 2001$ \\
\end{tabular}} & \multirow{2}{*}{$\begin{array}{c}\begin{array}{c}\text { Relative } \\
\text { change } \\
(\%)\end{array} \\
1991 \rightarrow 2001 \\
\end{array}$} & \multicolumn{2}{|c|}{$\begin{array}{c}\text { Absolute } \\
\text { levels } \\
\text { (ng/g lipid) }\end{array}$} & \multirow{2}{*}{\begin{tabular}{|c|}
$\begin{array}{c}\text { Absolute } \\
\text { change } \\
\text { (ng/g lipid) }\end{array}$ \\
$1991 \rightarrow 2001$
\end{tabular}} & \multirow{2}{*}{\begin{tabular}{|c|}
$\begin{array}{c}\text { Relative } \\
\text { change } \\
(\%)\end{array}$ \\
$1991 \rightarrow 2001$ \\
\end{tabular}} \\
\hline & & 1991 & 2001 & & & 1991 & 2001 & & & 1991 & 2001 & & \\
\hline Zero & Mean & 210 & 120 & -92 & -37 & 370 & 140 & -236 & -52 & 46 & 22 & -24 & -48 \\
\hline \multirow[t]{3}{*}{$(\mathrm{N}=18)$} & Median & 210 & 120 & -93 & -44 & 290 & 100 & -178 & -63 & 44 & 22 & -23 & -51 \\
\hline & Min & 22 & 38 & -185 & -57 & 27 & 25 & -737 & -83 & 19 & 14 & -61 & -65 \\
\hline & Max & 400 & 220 & 16 & 72 & 1000 & 330 & 42 & 154 & 94 & 33 & -1 & -6 \\
\hline Moderate & Mean & 510 & 370 & -139 & -30 & 1400 & 580 & -855 & -61 & 110 & 42 & -66 & -60 \\
\hline \multirow[t]{3}{*}{$(\mathrm{N}=12)$} & Median & 430 & 330 & -131 & -29 & 960 & 420 & -591 & -64 & 90 & 36 & -57 & -61 \\
\hline & Min & 180 & 74 & -273 & -59 & 170 & 41 & -3868 & -77 & 45 & 21 & -193 & -70 \\
\hline & Max & 1100 & 1000 & -15 & -4 & 6500 & 2600 & -132 & -24 & 290 & 96 & -24 & -46 \\
\hline High & Mean & 470 & 310 & -157 & -31 & 1400 & 690 & -730 & -54 & 98 & 43 & -55 & -55 \\
\hline \multirow[t]{3}{*}{$(\mathrm{N}=9)$} & Median & 420 & 250 & -135 & -21 & 1100 & 580 & -525 & -49 & 83 & 45 & -49 & -58 \\
\hline & Min & 150 & 110 & -473 & -75 & 330 & 29 & -2196 & -95 & 55 & 21 & -91 & -69 \\
\hline & Max & 1000 & 810 & 29 & 19 & 4500 & 2300 & -102 & -31 & 140 & 61 & -22 & -32 \\
\hline Alla & Mean & 360 & 240 & -122 & -34 & 940 & 400 & -540 & -55 & 77 & 33 & -44 & -53 \\
\hline \multirow[t]{3}{*}{$(\mathrm{N}=39)$} & Median & 340 & 170 & -101 & -38 & 650 & 200 & -397 & -61 & 67 & 26 & -36 & -56 \\
\hline & Min & 22 & 38 & -473 & -75 & 27 & 25 & -3868 & -95 & 19 & 14 & -194 & -70 \\
\hline & Max & 1100 & 1000 & 29 & 72 & 6500 & 2600 & 42 & 154 & 290 & 96 & -1 & -6 \\
\hline
\end{tabular}

